\title{
PRECAMBRIAN FOSSILS FROM THE KETILIDIAN OF SOUTH-WEST GREENLAND
}

\author{
K. Raunsgaard Pedersen
}

Ketilidian low-metamorphic rocks ca. $1700-2000 \mathrm{~m}$.y. old are exceptionally well preserved in the Grænseland-Midternæs area north-east of Ivigtut, South-West Greenland. During the mapping of these rocks structures of possible organic origin were found. A further examination of these structures together with the examination of rock samples from the whole series has shown that both macroscopic and microscopic organic structures are present. The best preserved type is a complex globular structure of about $1 / 2 \mathrm{~mm}$ in diameter (Vallenia erlingi Raunsgaard Pedersen), but most of the organic remnants are microscopic globules and fragments with cellular structures. A description of some of the structures is in press (Bondesen, Raunsgaard Pedersen and Jørgensen, in press). The organic remnants and the sediments of Grænseland are so well preserved that it has been possible to extract small amounts of distinctive organic compounds.

In the summer of 1966 field work was carried out in Grænseland for a few weeks to secure larger samples of the most suitable rocks for further micropalaeontological and organochemical studies. Another purpose of the work was to search for macroscopic fossil structures. The well preserved globular structure (Vallenia) known previously from three localities was only found at one new locality in the northern part of Grænseland. The fossil occurs here at the same stratigraphical position in the sedimentary series as the former finds, the uppermost part of the Grænses $\phi$ Formation. It is therefore now possible to state that this fossil has a very restricted occurrence in the sequence.

At a few localities other types of structures of possible organic origin were found. The best find was in the lowermost part of the Ketilidian series in Zig Zag Land in the central part of Grænseland. The fossils were found in a yellow dolomite layer just above the basal conglomerate. The fossils are irregular, tube formed and unbranching or dividing once. The diameter of the tubes varies from a few millimetres to about $10 \mathrm{~mm}$, the length of the tubes is up to about $40 \mathrm{~mm}$. These fossils occur in great abundance sitting at right angles to the bedding planes. 
Further investigations on the new macrofossil structures are in progress together with work on the microfossil structures and the organic compounds.

\section{Reference}

Bondesen, E. , Pedersen, K. Raunsgaard and Jørgensen, O. (in press) Precambrian organisms and the isotopic composition of organic remains in the Ketilidian of South-West Greenland. Medd. Grфnland, Bd. 164, Nr. 4.

\section{ULTRABASIC INTRUSIVES FROM NARSSAQ AND TUGTUTÔQ}

\section{B. G. J. Upton}

On the Panernaq peninsula [now named Ungussivik] north of Narssaq, five small outcrops of ultrabasic rock occur, the largest being some $200 \mathrm{~m}$ across. Conceivably these are connected at depth and should be regarded as probably comprising a single intrusion. The smallest (southernmost) of the outcrops is now, unfortunately, obscured by a Narssaq municipal refuse-tip. Two small bodies of similar ultrabasic material have been found on the eastern part of Tugtutô island. All these ultrabasic masses are associated with the large olivine gabbro intrusions (Upton, 1964) and are held to represent younger intrusions into, or adjacent to, the latter. They are themselves cut by the big feldspar dykes and by the trachyte and comendite dykes of the regional WSW-ENE swarms.

Typically these ultrabasic and ultramafic masses are composed of fine-grained rock with a hornfelsic appearance. The texture is generally decussate and equigranular with an average grain size of around $0.25 \mathrm{~mm}$. The colour is variable from black, brown, yellowish-brown to dull greenish. 